\title{
Effect of Phenylephrine and Prazosin on the Somatostatinergic System in the Rat Frontoparietal Cortex
}

\author{
SUSANA LÓPEZ-SAÑUDO, EULALIA RODRÍGUEZ-MARTÍN, ANGELA MARTÍN-ESPINOSA AND \\ EDUARDO ARILLA ${ }^{\prime}$
}

\author{
Unidad de Neuroendocrinología Molecular, Departamento de Bioquímica y Biología Molecular, Facultad de \\ Medicina, Universidad de Alcalá, E-28871, Alcalá de Henares, Madrid, Spain
}

Received 30 December 1994

\begin{abstract}
LÓPEZ-SAÑUDO. S., E. RODRÍGUEZ-MARTÍN, A. MARTÍN-ESPINOSA AND E. ARILLA. Effect of phenylephrine and prazosin on the somatostatinergic system in the rat frontoparietal cortex. PEPTIDES 16(8) 1453-1459, 1995. - Somatostatin (SS) and noradrenal ine (NA) are distributed in the rat cerehral cortex, and seizure activity is one of the aspects of behavior affected by both neurotransmitters. Due to the possible interaction between both neurotransmitter systems, we studied whether phenylphrine, an $\alpha_{1}$-adrencceptor agonist, and prazosin, an $\alpha_{1}$-adrenoceptor antagonist, can modulate SS-like immunoreactivity (SS-LI) levels, binding of $\left[^{125} \mathrm{I}\right]\left[\mathrm{Tyr}^{11}\right] \mathrm{SS}$ to its spccific receptors, the ability of SS to inhibit adenylate cyclase (AC) activity, and the guanine nucleotide binding regulatory protein $G_{i}$ and $G_{i}$ in the Sprague-Dawley rat frontoparietal cortex. An IP dose of 2 or 4 $\mathrm{mg} / \mathrm{kg}$ of phenylephrine injected $7 \mathrm{~h}$ before decapitation decreased the number of SS receptors and increased the apparent affinity in frontoparietal cortex membranes. An IP dose of $20 \mathrm{or} 25 \mathrm{mg} / \mathrm{kg}$ of prazosin administered $8 \mathrm{~h}$ before decapitation increased the number of SS receptors and decreased their apparent affinity. The administration of prazosin before the phenylephrine injection prevented the phenylephrine-induced changes in SS binding. The addition of phenylephrine and/or prazosin $10^{-5} M$ to the incubation medium changed neither the number nor the affinity of the SS receptors in the frontoparietal cortex membranes. Phenylephrine or prazosin affected neither SS-LI content nor the basal or forskolin (FK)-stimulated AC activities in the frontoparietal cortex. In addition, SS caused an equal inhibition of AC activity in frontoparietal cortex membranes of phenylephrine- and prazosintreated rats compared with the respective control group. Finally, phenylephrine and prazosin did not vary the pertussis toxin (PTX)catalyzed ADP ribosylation of $\mathrm{G}_{\mathrm{i}^{-}}$and/or $\mathrm{G}_{0}$-proteins. These results suggest that the above-mentioned changes are related to the phenylephrine activation of $\alpha_{1}$-adrenoceptors or to the blocking of these receptors by prazosin. In addition, these dala provide further support for a functional interrelationship between the $\alpha_{1}$-adrenergic and somatostatinergic systems in the rat frontoparietal cortex.
\end{abstract}

Phenylephrine Prazosin Somatostatin receptors Adenylate cyclase G-proteins Frontoparietal cortex

SOMATOSTATIN (SS), Prist identified as a tetradecapeptide in the hypothalamus (8), is one of the most highly concentrated and widely distributed peptides in the mammalian nervous system $(17,26,46)$. In the central nervous system (CNS), SS is a neurotransmitter that regulates neuronal activity and the release of other transmitters $(12,58)$. Significant amounts of SS have been detected in the cerebral cortex (15). In addition, cerebral cortex membranes contain one of the largest concentrations of SS receptors $(29,37,40,52,57,60)$. Noradrenergic fibers originating in the locus coeruleus are also widely distributed in the cerebral cortex $(9,24,32)$. In the rat neocortex, $\alpha_{1}$ adrenoceptors have been localized by autoradiography to lamina I and lamina $\mathrm{Va}$ and $\mathrm{Vc}$, sparing the layer $\mathrm{Vb}$ pyramidal cells (27). Somatostatinergic and noradrenergic neurotransmission modulate neuronal firing $(15,49)$. Seizure activity is one of the aspects of behavior affected by SS. Applied to rats, SS causes general tonic-clonic seizures that are mediated through local depression of EEG activities and/ or epileptic spiking in the cortex, hippocampus, and striatum (23). The central noradrenergic system also plays an important role in the regulation of cortical neuronal excitability (49). Drugs or lesions that deplete brain stores of noradrenaline (NA) are known to facilitate seizures in many species, including humans (11). The highly selective $\alpha_{1}$ agonist SE 587 , which easily penetrates the blood-brain barrier, displays significant anticonvulsant activity in both epileptic gerbils (33) and in rats with spontaneous petit mal-like seizures (39).

The present study was undertaken to determine whether the $\alpha_{1}$-adrenergic system can modulate the somatostatinergic system in the rat frontoparietal cortex. Therefore, we used phenylephrine, an $\alpha_{1}$-adrenoceptor agonist, and prazosin, an $\alpha_{1}$-adreno-

\footnotetext{
' Requests for reprints should be addressed to Eduardo Arilla.
} 
ceptor antagonist, to evaluate their effects on the [ $\left.{ }^{125} \mathrm{I}\right]\left[\mathrm{Tyr}^{1}\right] \mathrm{SS}$ binding to its specific receptors, SS-modulated adenylate cyclase (AC) activity, expression of the $\alpha$ subunit of the guanine nucleotide regulatory proteins $\mathrm{G}_{\mathrm{i}}$ and $\mathrm{G}_{\mathrm{o}}$, and SS-like immunoreactivity (SS-LI) concentration in the rat frontoparietal cortex.

\section{METHOD}

\section{Chemicals}

Synthetic [Tyг $\left.{ }^{11}\right] S S$ and SS tetradecapeptide were purchased from Universal Biologicals Ltd (Cambridge, UK); phenylephrine hydrochloride, bacitracin, phenylmethylsulfonyl fluoride (PMSF), 3-isobutyl-1-methylxanthine (IBMX), pertussis toxin (PTX), bovine serum albumin (BSA), GTP, forskolin (FK), and prestained protein markers and other reagents for sodium dodecyl sulfatepolyacrylamide gel electrophoresis (SDS-PAGE) were supplied by Sigma Química (Madrid, Spain); prazosin hydrochloride (Minipres) from Pfizer (Madrid, Spain); and carrier-free $\mathrm{Na}^{125} \mathrm{I}$ (IMS $30,100 \mathrm{mCi} / \mathrm{ml}$ ) from the Radiochemical Centre (Amersham, UK). ['Tyr "]SS was radioiodinated by the chloramine- $T$ method (21). The tracer was purified on a Sephadex G-25 coarse column $(1 \times 100)$, which had been equilibrated with $0.1 M$ acetic acid, containing BSA $0.1 \%(\mathrm{w} / \mathrm{v})$. Specific tracer radioactivity was about $600 \mathrm{Ci} / \mathrm{mmol}$. The rabbit antibody used in the radioimmunoassay technique was purchased from the Radiochemical Centre. This antiserum was raised in rabbits against SS-14 conjugated to BSA and is specific for SS, but because SS-14 also constitutes the $C$-terminal portions of both SS-25 and SS-28, the antiserum does not distinguish between these three forms. Crossreactivity with other peptides was less than $0.5 \%$. Cross-reaction with several SS analogues demonstrated that neither the $N$-terminal glycine nor the $C$-terminal cystcinc residuc is required for antibody binding, suggesting that the antigen site is directed towards the central part of the molecule containing the tryptophan residue. The binding of SS-14 to its antibody does not depend on an intact disulfide bond in the molecule, because breaking of the disulfide bond by reaction with $0.1 \%$ mercaptoethanol (boiling water bath, $5 \mathrm{~min}$ ) did not change peptide immunoreactivity.

\section{Experimental Animals}

The animals used in this study were Sprague-Dawley rats ( $n=60$ ) weighing between 200 and $250 \mathrm{~g}$. Rats were maintained on a 12-h light/dark cycle $(0700-1900 \mathrm{~h})$ and allowed free access to food. Phenylephrine $(0.5,2$, and $4 \mathrm{mg} / \mathrm{kg})$ and prazosin $(5,20$, and $25 \mathrm{mg} / \mathrm{kg}$ ) were dissolved in distilled water or propylene glycol $25 \%$, respectively, as previously described $(5,6)$. Fresh solutions were prepared every day just prior to administration. Drugs were diluted such that injections were in volumes of 2.0 $\mathrm{ml} / \mathrm{rat}$ and were administered IP $7 \mathrm{~h}$ (phenylephrine) or $8 \mathrm{~h}$ (prazosin) prior to assay. In another experimental group, prazosin ( 20 $\mathrm{mg} / \mathrm{kg}, \mathrm{IP}$ ) was administered $1 \mathrm{~h}$ before phenylephrine $(2 \mathrm{mg} / \mathrm{kg}$, IP). Control animals for each group cited were injected with equivalent volumes of distilled water, propylene glycol $25 \%$, or propylene glycol $25 \%$ plus distilled water according to whether the corresponding experimental group was to be injected with phenylephrine, prazosin, or prazosin plus phenylephrine, respectively. Drug doses were selected according to the effective dose reported in previous studies $(5,6)$. Rats were killed by decapitation at 7 or $8 \mathrm{~h}$ after the last injection, as appropriate. The brain was rapidly removed and the frontoparietal cortex was dissected over ice according to the method of Glowinski and Iversen (20).

\section{Tissue Extraction and SS Radioimmunoassay}

For SS-LI measurements, the frontoparietal cortex was rapidly homogenized using a Brinkman polytron (setting $5,30 \mathrm{~s}$ ), in $1 \mathrm{ml} 2 \mathrm{M}$ acetic acid. Extracts were boiled for $5 \mathrm{~min}$ in a water bath, chilled in ice, and aliquots $(100 \mu \mathrm{l})$ were removed for protein determination (34). Subsequently, homogenates were centrifuged at $15,000 \times g$ for $15 \mathrm{~min}$ at $4^{\circ} \mathrm{C}$, and the supernatant was neutralized with $2 M \mathrm{NaOH}$. Extracts were immediately stored at $-70^{\circ} \mathrm{C}$ until assay. SS-LI level was determined in tissue extracts by a modified radioimmunoassay method (45), with a sensitivity limit of $10 \mathrm{pg} / \mathrm{rnl}$. Incubation tubes prepared in duplicate contained $100-\mu 1$ samples of unknown or standard solutions of $0-500$ pg cyclic SS tetradecapeptide diluted in phosphate buffer $(0.05 M, \mathrm{pH} 7.2$ containing $0.3 \%$ BSA, $0.01 M$ EDTA), 200 $\mu \mathrm{l}$ of appropriately diluted antiserum, $100 \mu \mathrm{l}$ of freshly prepared $\left.{ }^{125} I\right]\left[\right.$ Tyr $\left.^{11}\right]$ SS diluted in buffer to give $6000 \mathrm{cpm} /$ assay tube (equivalent to $5-10 \mathrm{pg}$ ), and enough buffer to give a final volume of $0.8 \mathrm{ml}$. All reagents as well as the assay tubes were kept chilled on ice before incubation at $4^{\circ} \mathrm{C}$ for $48 \mathrm{~h}$. Separation of bound and free hormone was accomplished by the addition of $1 \mathrm{ml}$ dextrancoated charcoal (dextran 170: 0.2\% w/v, Pharmacia, Uppsala, Sweden; charcoal: Norit A $2 \%$ w/v, Serva, Feinbiochemica, Heidelberg, Germany). Dilution curve for this brain area was parallel to the standard curve. The intra- and interassay variation coefficients were $6.8 \%$ and $8.1 \%$, respectively.

\section{Binding Assay for Membrane Preparations}

Frontoparietal cortex membranes were prepared as described by Reubi et al. (52). Proteins were assayed by the method of Lowry et al. (34), with BSA as a standard. Specific SS binding was measured according to the modified method of Czernik and Petrack (13). The membranes $(0.15 \mathrm{mg}$ protein $/ \mathrm{ml})$ were incubated in $0.25 \mathrm{ml}$ of a medium containing $50 \mathrm{~m} M$ Tris-HCl buffer (pH 7.5), $5 \mathrm{mM} \mathrm{MgCl}, 0.2 \%$ (w/v) BSA, and $0.1 \mathrm{mg} / \mathrm{ml}$ bacitracin with $250 \mathrm{pM}\left[{ }^{125} \mathrm{I}\right]\left[\mathrm{Tyr}^{11}\right.$ ]SS cither in the absence or in the presence of $0.01-10 \mathrm{nM}$ unlabeled SS. After 60-min incubation at $30^{\circ} \mathrm{C}$, membrane-bound peptide was isolated by centrifugation at $11,000 \times \mathrm{g}$ for $2 \mathrm{~min}$, and radioactivity was determined in a Kontron gamma counter. Specific binding was defined as the difference in the amount of radioligand bound in the absence and presence of $10^{-7} \mathrm{MSS}$.

\section{Evaluation of Radiolabeled Peptide Degradation}

To determine the extent of tracer degradation during incubation, we measured the ability of preincubated peptide to bind to fresh frontoparietal cortex membranes as previously described (1). Briefly, $\left.{ }^{125} \mathrm{I}\right]\left[\mathrm{Tyr}^{11}\right] \mathrm{SS}(250 \mathrm{pM})$ was incubated with membranes from rat frontoparietal cortex $(0.15 \mathrm{mg}$ protein $/ \mathrm{ml})$ for 60 min at $30^{\circ} \mathrm{C}$. After this preincubation, aliquots of the medium were added to fresh membranes and incubated for an additional $60 \mathrm{~min}$ at $30^{\circ} \mathrm{C}$. The fraction of the added radiolabeled peptide, which was specifically bound during the second incubation, was measured and expressed as a percentage of the binding that had heen obtained in control experiments performed in the absence of membranes during the preincubation period.

\section{Adenylate Cyclase Assay}

The AC activity was measured as previously reported (25) with minor modifications (22). Briefly, rat frontoparietal cortex membranes $(0.06 \mathrm{mg} / \mathrm{ml})$ were incubated with $1.5 \mathrm{~m} M$ ATP, 5 $\mathrm{mM} \mathrm{MgSO}{ }_{4}, 10 \mu M$ GTP, an ATP-regenerating system (7.5 mg/ $\mathrm{ml}$ creatine phosphate and $1 \mathrm{mg} / \mathrm{ml}$ creatine kinase), $1 \mathrm{~m} M$ 


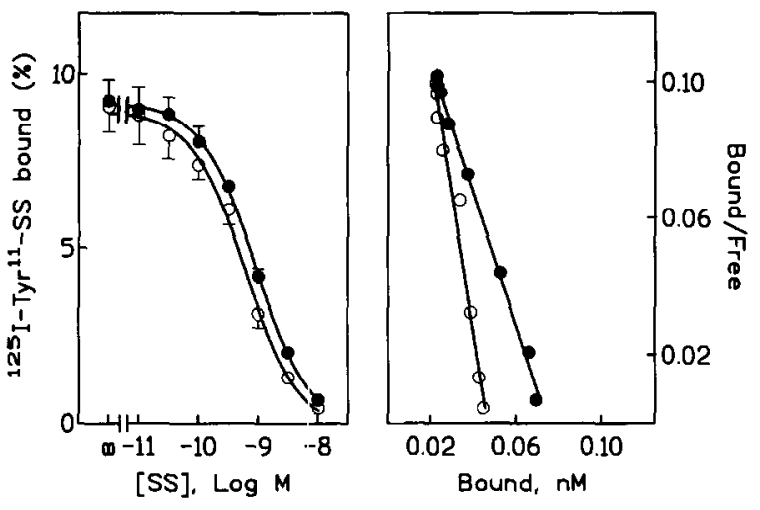

FIG. 1. Effects of in vivo phenylephrine administration on somatostatin (SS) binding to frontoparietal cortex membranes. Left panel: competitive inhibition of specific [ [25)][Tyr $\left.{ }^{13}\right]$ SS binding by unlabeled SS to frontoparietal cortex membranes. Membranes $(0.15 \mathrm{mg}$ protein $/ \mathrm{ml})$ were incubated for $60 \mathrm{~min}$ at $30^{\circ} \mathrm{C}$ in the presence of $250 \mathrm{pM}$ [ $\left.{ }^{125} \mathrm{I}\right]\left[\mathrm{Tyr}^{\prime \prime}\right] \mathrm{SS}$ and increasing concentrations of native peptide. Points correspond to values for the animals in the control group ( $)$ and phenylephrine-treated group $(\mathrm{O})$. Each point is the mean $\pm \mathrm{SEM}$ of five replicate experiments. Right panel: Scatchard analysis of the same data.

IBMX, $0.1 \mathrm{~m} M$ PMSF, $1 \mathrm{mg} / \mathrm{ml}$ bacitracin, $1 \mathrm{~m} M$ EDTA, and test substances $\left(10^{-4} M \mathrm{SS}\right.$ or $\left.10^{-5} M \mathrm{FK}\right)$ in $0.1 \mathrm{ml}$ of $0.025 M$ triethanolamine- $\mathrm{HCl}$ buffer ( $\mathrm{pH} 7.4$ ). After 15-min incubation at $30^{\circ} \mathrm{C}$, the reaction was stopped by heating the mixture for $3 \mathrm{~min}$. After refrigeration, $0.2 \mathrm{ml}$ of an alumina slurry $(0.75 \mathrm{~g} / \mathrm{ml}$ in triethanolamine-HCl buffer, $\mathrm{pH}$ 7.4) was added and the suspension was centrifuged. The supernatant was taken to assay the cyclic AMP (cAMP) by using the method of Gilman (19). The SS concentration used was the one that is known to inhibit rat $(42,54)$ and human (18) brain AC. FK was used at a concentration of $10^{-5} M$, which primarily stimulates the catalytic subunit of $\mathrm{AC}(55)$

\section{Pertussis Toxin-Catalyzed ADP Ribosylation}

The PTX-catalyzcd ADP ribosylation was carried out as previously reported (7). After PTX activation, membranes $(0.8 \mathrm{mg}$ of protein $/ \mathrm{ml})$ were incubated with PTX $(16 \mu \mathrm{g} / \mathrm{ml})$ in $100 \mathrm{mM}$ Tris-Cl buffer ( $\mathrm{pH} \mathrm{8.0)}$, containing $10 \mathrm{~m} M$ thymidine, $1 \mathrm{~m} M$ ATP, $100 \mu M$ GTP, $2.5 \mathrm{~m} M \mathrm{MgCl}_{2}, 1 \mathrm{~m} M$ EDTA, $1 \mu M$ $\left.{ }^{32} \mathrm{P}\right] \mathrm{NAD}^{+}(30 \mathrm{Ci} / \mathrm{mm}$ ol $)$, and an ATP-regenerating system. After $30 \mathrm{~min}$ at $30^{\circ} \mathrm{C}$, the reaction was stopped by addition of $1 \mathrm{ml}$ of ice-cold $100 \mathrm{mM}$ Tris- $\mathrm{HCl}$ buffer ( $\mathrm{pH} 8.0$ ), sedimented by centrifugation for $10 \mathrm{~min}$ at $30,000 \times g$ and the pellet was solubilized with $0.1 \mathrm{ml}$ of $60 \mathrm{mM}$ Tris- $\mathrm{HCl}$ buffer ( $\mathrm{pH} \mathrm{6.8)} \mathrm{con-}$ taining $10 \%$ glycerol, $0.001 \%$ bromophenol blue, and $3 \%$ SDS (SDS sample buffer). After heating for $30 \mathrm{~min}$ at $60^{\circ} \mathrm{C}$, the suspension was centrifuged for $10 \mathrm{~min}$ at $100,000 \times g$ and aliquots of the supernatant were submitted to SDS-PAGE, using the procedure of Laemmli (31) as previously described (30). The gels were run, fixed, dried, and exposed to Dupont films (cronex 4) for $1-7$ days at $-80^{\circ} \mathrm{C}$, using an intensifying screen.

\section{Data Analysis}

The LIGAND computer program (41) was used to analyze the binding data. The use of this program enabled models of receptors that best fit a given set of binding data to be selected. The same program was also used to present data in the form of Scatchard plots (53) and to compute values for receptor affinity
$\left(K_{\mathrm{f}}\right)$ and density $\left(B_{\max }\right)$ that best fit the sets of binding data for each rat. Statistical comparisons of all the data were carried out with one-way analysis of variance (ANOVA) and the Student's Newman-Keuls test. Means among groups were considered significantly different when $p<0.05$. Each individual experiment was performed in duplicate.

\section{RESULTS}

The specific binding of $\left[{ }^{125} \mathrm{I}\right]\left[\mathrm{Tyr}^{11}\right] \mathrm{SS}$ to membranes from rat frontoparietal cortex in all rat groups bound $\left[{ }^{125} \mathrm{I}\right]\left[\mathrm{Tyr}^{\mathrm{h}}\right.$ ] $\mathrm{SS}$ in a time-dependent fashion; an apparent equilibrium was observed between 50 and $180 \mathrm{~min}$ at $30^{\circ} \mathrm{C}$ (data not shown). All subsequent binding experiments were therefore conducted at $30^{\circ} \mathrm{C}$ for $60 \mathrm{~min}$. Peptide degradation was determined to rule out the possibility of different SS-degrading activities in all the preparations that might have affected the interpretation of the results. Membranes from frontoparietal cortex showed a similar peptide degradation capacity, and the values varied by no more than $10 \%$ in all the experimental groups.

Phenylephrine administration at a dose of 2 or $4 \mathrm{mg} / \mathrm{kg}$ produced a significant decrease in [ $\left.{ }^{125} \mathrm{I}\right]\left[\mathrm{Tyr}^{\prime \prime}\right] \mathrm{SS}$ binding to rat frontoparietal cortex membranes compared with controls, with no difference detected between both doses (Table 1 and Fig. 1, left panel). This decrease was due to a decrease in the number of SS receptors as revealed by Scatchard plots of the binding data (Fig. 1 , right panel). In addition, a significant increase in the affinity of these receptors was observed at both of these doses (Table 1). No changes in the SS receptor number and affinity were observed at the lowest dose studied (Table 1). Therefore, subsequent studies were carried out with $2 \mathrm{mg} / \mathrm{kg}$, the dose frequently used by other investigators $(5,6)$.

Prazosin administration at a dose of 20 or $25 \mathrm{mg} / \mathrm{kg}$ significantly increased $\left[{ }^{125} \mathrm{I}\right]\left[\mathrm{Tyr}^{11}\right] \mathrm{SS}$ binding to rat frontoparietal cor-

\section{TABLE 1}

EFFECT OF PHENYLEPHRINE. PRAZOSIN. AND PRAZOSIN PLUS PHENYLEPHRINE ON SS-LI CONCENTRATION AND EQUILIBRIUM PARAMETERS FOR SS BINDING TO FRONTOPARIETAL CORTEX MEMBRANES

\begin{tabular}{llll}
\hline & \multicolumn{2}{c}{ SS Receptors } & \\
\cline { 2 - 3 } \multicolumn{1}{c}{ Groups } & \multicolumn{1}{c}{$B_{\text {max }}$} & \multicolumn{1}{c}{$K_{4}$} & SS-LI \\
\hline $\begin{array}{l}\text { Control } \\
\text { Phenylephrine }\end{array}$ & $488 \pm 16$ & $0.50 \pm 0.07$ & $10.20 \pm 0.47$ \\
$\quad 0.5 \mathrm{mg} / \mathrm{kg}$ & $456 \pm 35$ & $0.57 \pm 0.08$ & \\
$2 \mathrm{mg} / \mathrm{kg}$ & $304 \pm 28^{*}$ & $0.24 \pm 0.006^{*}$ & $9.38 \pm 0.70$ \\
$4 \mathrm{mg} / \mathrm{kg}$ & $318 \pm 6^{*}$ & $0.29 \pm 0.01^{*}$ & \\
Control & $445 \pm 37$ & $0.52 \pm 0.07$ & $9.09 \pm 0.62$ \\
Prazosin & & & \\
$5 \mathrm{mg} / \mathrm{kg}$ & $503 \pm 14$ & $0.98 \pm 0.11^{*}$ & \\
$20 \mathrm{mg} / \mathrm{kg}$ & $775 \pm 82 \dagger$ & $0.98 \pm 0.11^{*}$ & $9.01 \pm 0.58$ \\
$25 \mathrm{mg} / \mathrm{kg}$ & $748 \pm 19 \dagger$ & $1.08 \pm 0.11^{*}$ & \\
Control & $490 \pm 22$ & $0.43 \pm 0.04$ & $8.97 \pm 1.32$ \\
Prazosin (20 mg/kg) & & & \\
plus phenylephrine & & & \\
$\quad(2 \mathrm{mg} / \mathrm{kg})$ & $492 \pm 40$ & $0.51 \pm 0.06$ & $9.39 \pm 0.61$ \\
\hline
\end{tabular}

Binding parameters were calculated from Scatchard plots by linear regression. Units for SSLI are ng SS per mg protein, units for $k_{\mathrm{d}}$ are $\mathrm{n} M$, and units for $B_{\text {max }}$ are fmol of SS bound per mg of protein. The results are represented as the means \pm SEM of five separate experiments.

$*+$ Statistical comparison versus control: $* p<0.05, \dagger p<0.01$. 
tex membranes compared with controls, with no difference detected between both doses (Table 1 and Fig. 2, left panel). This increase was due to a rise in the maximum number of SS receptors as revealed by Scatchard plots of the binding data (Fig. 2, right panel). In addition, a significant decrease in the affinity of these receptors was observed at both of these doses (Table 1). No changes in the SS receptor number and affinity were observed at the lowest dose studied (Table 1). Therefore, subsequent studies were carried out with $20 \mathrm{mg} / \mathrm{kg}$, a dose frequently used by other investigators $(5,6)$. Pretreatment with prazosin $(20 \mathrm{mg} / \mathrm{kg})$ completely blocked the changes in the number and affinity constant of SS receptors induced by phenylephrine $(2 \mathrm{mg} / \mathrm{kg}) \mathrm{ad}-$ ministration (Table 1 and Fig. 3).

To assess whether phenylephrine or prazosin exert a direct action on SS receptors, $10^{-5} M$ phenylephrine or prazosin was included in the incubation medium at the time of the binding assay with membranes from frontoparietal cortex of normal rats. The addition of phenylephrine or prazosin to the incubation medium changed neither the number nor the affinity of the SS receptors (data not shown).

In the brain, SS binds to its specific receptors and regulates the AC system via guanine nucleotide binding regulatory proteins (G-proteins), which are sensitive to PTX $(18,42,60)$. Therefore, we studied the PTX substrates in frontoparietal cortex after the treatment with phenylephrine and prazosin. PTX induced the incorporation of ${ }^{32} \mathrm{P}$ in a $41 \mathrm{kDa}\left(\mathrm{G}_{\mathrm{i} \alpha}\right)$ and $39 \mathrm{kDa}\left(\mathrm{G}_{\mathrm{o} \alpha}\right)$ protein under the conditions studied here (Fig. 4). Phenylephrine and prazosin had no effect on the PTX-catalyzed ADP ribosylation of $\mathrm{G}_{i}$ and $\mathrm{G}_{\mathrm{o}} \alpha$ subunits (Fig. 4).

To study SS-modulated AC activity, frontoparietal membranes were incubated with SS $\left(10^{-4} M\right)$, with or without FK $\left(10^{-5} M\right)$, a direct AC activator. No significant differences in basal or FK-stimulated AC activity were observed between the control, phenylephrine, prazosin, and prazosin plus phenylephrine groups in frontoparietal cortex membranes (Table 2). In all experimental groups, SS inhibited the basal and the FK-stimulated $\mathrm{AC}$ activities. The treatment with phenylephrine and/or prazosin did not modify the capacity of SS to inhibit the basal

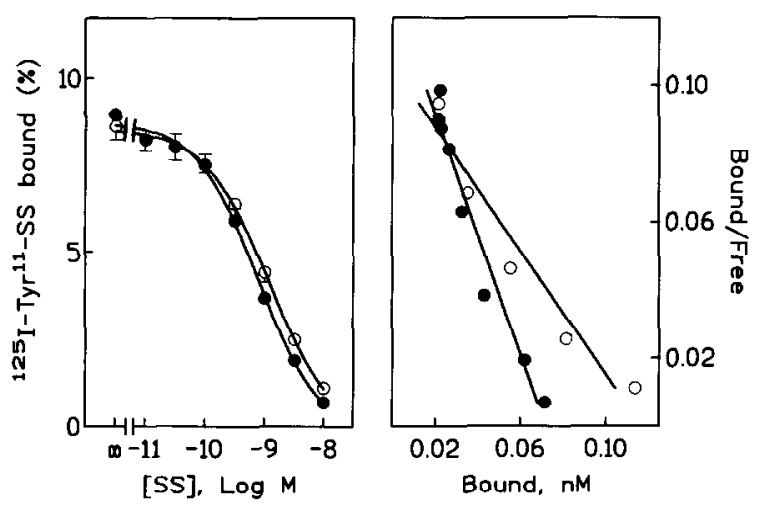

FIG. 2. Effect of in vivo prazosin administration on somatostatin (SS) binding to frontoparietal cortex membranes. Left panel: competitive inhibition of specific $\left.{ }^{125} \mathrm{I}\right]\left[\mathrm{Tyr}^{\prime \prime}\right] \mathrm{SS}$ binding by unlabeled SS to frontoparietal cortex membranes. Membranes $(0.15 \mathrm{mg}$ protein/ml) were incubated for $60 \mathrm{~min}$ at $30^{\circ} \mathrm{C}$ in the presence of $250 \mathrm{pM}\left[{ }^{125} \mathrm{I}\right]\left[\mathrm{Tyr}{ }^{i 1}\right] \mathrm{SS}$ and increasing concentrations of native peptide. Points correspond to values for the animals in the control group $(\bullet)$ and prazosin-treated group $(O)$. Each point is the mean \pm SEM of five replicate experiments. Right panel: Scatchard analysis of the same data.
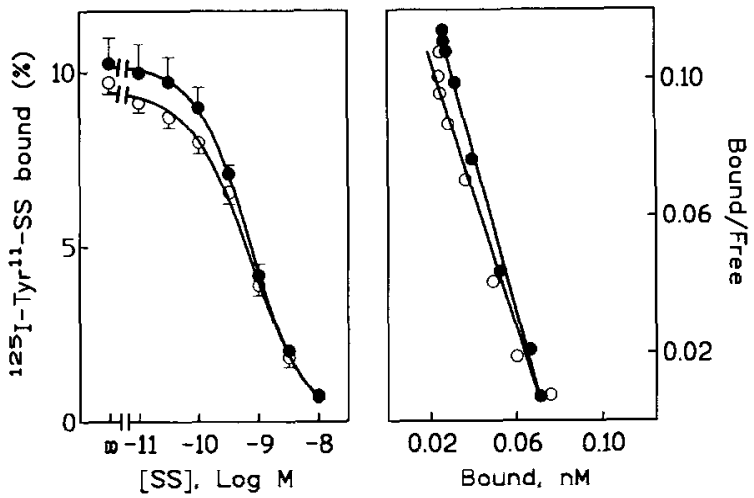

FIG. 3. Effect of in vivo prazosin plus phenylephrine administration on somatostatin (SS) binding to frontoparietal cortex membranes. Left panel: competitive inhibition of specific [ $\left.{ }^{125} \mathrm{I}\right]\left[\mathrm{Tyr}^{1}\right] \mathrm{SS}$ binding by unlabeled SS to frontoparietal cortex membranes. Membranes $(0.15 \mathrm{mg}$ protein $/ \mathrm{ml}$ ) were incubated for $60 \mathrm{~min}$ at $30^{\circ} \mathrm{C}$ in the presence of 250 $\mathrm{p} M\left[{ }^{12.5} \mathrm{I}\right]\left[\mathrm{Tyr}^{\prime \prime}\right] \mathrm{SS}$ and increasing concentrations of native peptide. The points correspond to the values for the animals in the control group ( and prazosin plus phenylephrine-treated group $(O)$. Each point is the mean of five replicate experiments. Right panel: Scatchard analysis of the same data.

and FK-stimulated $\mathrm{AC}$ activity, in comparison with the respective control groups (Table 2).

The administration of either phenylephrine, prazosin, and/or prazosin plus phenylephrine did not affect SS-LI content in frontoparietal cortex in comparison with the respective control group (Table 1).

\section{DISCUSSION}

This study indicates that the administration of phenylephrine decreased the number of specific SS receptors in the frontoparietal cortex, while increasing receptor affinity. Pretreatment with the $\alpha_{1}$-adrenergic antagonist prazosin prevented the phenylephrine-induced changes in the binding of SS, whereas prazosin alone increased SS binding to its receptor.

In previous studies, the time course of the phenylephrine and prazosin effect on the binding of steroid ligand to estrogen $(5,6)$ and progestin receptors (38), it was found that in scveral regions of the CNS of adult rats the change in the number of specific receptors was first detectable at 7 or $8 \mathrm{~h}$ after a single injection; at $16 \mathrm{~h}$, the number of specific receptors had returned to baseline levels. In the present study, the treatment intervals were selected according to these studies. The phenylephrine and prazosin doses selected in the present study are similar to those used by other authors $(5,6)$.

The levels of SS-LI in the frontoparietal cortex as well as the binding parameters of the SS receptors in this brain area in the control rats were similar to those previously reported $(16,47,51,57)$. Although the Scatchard plots appear to be linear, this is no proof for receptor homogeneity. Indeed, it has been demonstrated for many years that SS binding in rat brain is heterogeneous $(43,53)$. It has been demonstrated recently that there are five cloned receptors expressed in the brain and that all have a similar high affinity for SS $(3,10)$. Thus, a linear Scatchard plot indicates only that the labeled sites have a similar affinity for the radioligand used.

The stimulation of $\alpha_{1}$ adrenoceptors primarily stimulates the phospholipase $\mathrm{C}$-catalyzed breakdown of phosphoinositides, leading to the generation of inositol triphosphate and diacylgly- 


\section{Phenylephrine Prazosin \\ Control Treated Control Treatod}
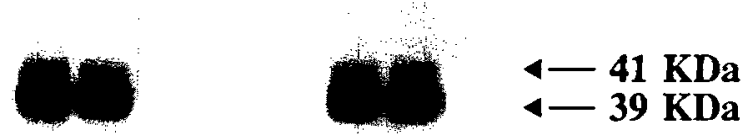

\section{Portusels toxin}

FIG. 4. Autoradiography of [ $\left.{ }^{32} \mathrm{P}\right]$ ADP-ribosylated brain membrane proteins. Frontoparietal cortex membranes $(0.8 \mathrm{mg}$ protein/ $\mathrm{ml})$ from controls, phenylephrine-treated, and prazosin-treated rats were incubated for $30 \mathrm{~min}$ at $30^{\circ} \mathrm{C}$ in the presence of $\left[{ }^{32} \mathrm{P}\right] \mathrm{NAD}^{+}$, with $(+)$or without $(-)$pertussis toxin $(16 \mu \mathrm{g} / \mathrm{ml})$. This experiment is representative of six others.

cerol (38). A series of recent reports has suggested that diacylglycerol derived from phosphatidylinositol breakdown is directly involved in the transmembrane control of protein phosphorylation through the activation of protein kinase $C$ (43). It is tempting to speculate that the decrease in labeled SS binding induced by activation of $\alpha_{1}$ adrenoceptors might be a consequence of the activation of protein kinase $C$ by diacylglycerol. In this regard, Matozaki et al. (36) have reported that diacylglycerol modulates SS binding to its receptors on rat pancreatic acinar cell membranes.

In our experiments, SS inhibited frontoparietal cortex $\mathrm{AC}$ activity in rats, a finding that is in agreement with the literature $(35,42,54)$. A relatively high concentration of SS $\left(10^{-4} M\right)$ is required to produce inhibition. Other authors $(4,18,42,54)$ used the same concentration in their studies on SS inhibition of human and rat brain AC. There is evidence suggesting that the effect of SS on AC activity is receptor mediated, rather than being a nonspecific inhibitory effect.

The SS concentration necessary to elicit the maximal inhibition of AC activity was about threefold that necessary to displace $\left[{ }^{[25} \mathrm{I}\right]\left[\mathrm{Tyr}^{\mathrm{i}}\right] \mathrm{SS}$ binding to its receptors. This apparent discrepancy may be explained observing that the PTX-sensitive G-proteins can modulate the affinity of SS receptors and/or the receptor coupling to the transduction system (AC among others). In this respect, Enjalbert et al. (14) and Koch and Schonbrunn (28) have shown that GTP-induced mobilization of the G-protein reduces
SS receptor affinity of the neuropeptide in cerebral cortical cells and in $\mathrm{GH}_{4} \mathrm{C}_{1}$ pituitary cell clones.

The changes in the number of SS receptors following agonist or antagonist $\alpha_{1}$-adrenoceptor administration was not accompanied by a corresponding modification in SS-inhibited $\mathrm{AC}$ activity. Some of these receptors are coupled by PTXsensitive guanine nucleotide binding proteins (G-proteins) to a variety of cellular effector systems and mediate the inhibition by SS of $\mathrm{AC}(48,54)$ and voltage-sensitive $\mathrm{Ca}^{2+}$ channel activity (63), as well as stimulation of $\mathrm{K}^{+}$channel activity (62). Other cellular actions of SS, including its antiproliferative effects (61) and regulation of $\mathrm{Na}^{+} / \mathrm{H}^{+}$exchange (2), appear to be mediated by PTX-insensitive mechanisms, indicating heterogeneity of receptor-effector interactions. Therefore, it is possible that the SS receptors modified by the $\alpha_{1}$ adrenergic system have not been functionally coupled to guanine nucleotide regulatory protein $G_{i}$, and may represent spare receptors, or a subpopulation of SS receptors that are coupled to an alternative second messenger system.

An inconsistency between changes in receptors and signal transduction is not unprecedented. For example, chronic exposure of primary cultures of mouse cortical neurons to the muscarinic antagonist atropine has been shown to increase the density of muscarinic receptors while decreasing carbacholstimulated phosphoinositide hydrolysis (56). Alternatively, the lack of correlation between the magnitude of SS inhibition

TABLE 2

EFFECT OF SS AND FK ON BRAIN AC ACTIVITY (pmol cAMP/min/mg protein)

\begin{tabular}{|c|c|c|c|c|c|c|c|c|c|c|c|}
\hline \multirow[b]{3}{*}{ Basal activity } & \multicolumn{4}{|c|}{ Phenylephrine $(n=5)$} & \multicolumn{3}{|c|}{$\operatorname{Prazosin}(n-5)$} & \multicolumn{4}{|c|}{ Prazosin Plus Phenylephrine $(n=5)$} \\
\hline & \multicolumn{2}{|c|}{ Control } & \multicolumn{2}{|c|}{ Treated } & \multicolumn{2}{|c|}{ Control } & Treated & \multicolumn{2}{|c|}{ Control } & \multicolumn{2}{|c|}{ Treated } \\
\hline & 288 & \pm 6 & 267 & \pm 15 & 323 & \pm 7 & \pm 6 & 321 & \pm 4 & 322 & \pm 12 \\
\hline Basal activity $+10^{-4} M \mathrm{SS}$ & 215 & \pm 10 & 207 & \pm 13 & 239 & \pm 7 & \pm 12 & 254 & \pm 5 & 254 & \pm 11 \\
\hline SS inhibition of basal activity (\%) & 26 & \pm 3 & 23 & \pm 2 & 26 & \pm 1 & \pm 3 & 21 & \pm 2 & 21 & \pm 1 \\
\hline$+10^{-5} M$ FK & 781 & \pm 6 & 643 & \pm 25 & 925 & \pm 11 & $922 \pm 19$ & 930 & \pm 35 & 939 & \pm 89 \\
\hline Fold FK stimulation over basal & 2. & \pm 0.1 & & \pm 0.1 & & $\perp 0.1$ & $2.8 \pm 0.1$ & & \pm 0.1 & & \pm 0.1 \\
\hline $10^{-5} M$ FK $+10^{-4} M$ SS & 587 & \pm 9 & 473 & \pm 23 & 648 & \pm 43 & $665 \pm 31$ & 691 & \pm 32 & 696 & \pm 28 \\
\hline SS inhibition of FK stimulation (\%) & 25 & \pm 2 & 26 & \pm 2 & 30 & \pm 4 & \pm 4 & 26 & \pm 1 & 26 & \pm 4 \\
\hline
\end{tabular}

Experiments were performed as described in the Method section. Values represent the mean \pm SEM of the determinations performed. 
of $\mathrm{AC}$ and the density of $\left[{ }^{125} \mathrm{I}\right]\left[\mathrm{Tyr}^{11}\right] \mathrm{SS}$ receptors seems to suggest the coupling of SS receptors to multiple signal transduction mechanisms or may be related to factors such as multiple and spare receptors sites. Of relevance to this observation is a recent report demonstrating no apparent match between the level of SS receptor sites and the magnitude of SS inhibition of $\mathrm{AC}$ activity in the frontal cortex of a group of $\mathrm{Al}$ zheimer's disease patients (4).

The functional significance of these findings remains to be clarified. Because SS and its receptors are present in the frontoparietal cortex and there are studies indicating that $\mathrm{SS}$ causes general tonic-clonic seizures when applied to rats (23), it is tempting to speculate that the anticonvulsant activity by stimulation of $\alpha_{1}$ adrenoceptors $(33,39)$ may, at least in part, depend on a decrease in the number of SS receptors.

\section{ACKNOWLEDGEMENTS}

The authors thank Carol F. Warren from the Alcalá de Henares University Institute of Education Sciences for her linguistic assistance, and Mr. Luis Monge for assistance in the preparations of the illustrations. This study was supported by a Grant (PB 94-0339) from the Dirección General de Investigación Científica y Técnica of Spain.

\section{REFERENCES}

1. Aguilera, G.; Parker, D. S.; Catt, K. J. Characterization of somatostatin receptors in the rat adrenal glomerulosa zone. Endocrinology $111: 1376-1384 ; 1982$

2. Barber, D. L.; McGuire, M. E.; Ganz, B. $\beta$-adrenergic and somatostatin receptors regulate $\mathrm{Na}^{+}-\mathrm{H}^{+}$exchange independent of cAMP. J Biol. Chem. 264:21038-21042; 1989.

3. Bell, G. I.; Reisine, T. Molecular biology of somatostatin receptors Trends Neurol. Sci. 16:34-38; 1993.

4. Bergström, L.; Garlind, A.; Nilsson, L.; et al. Regional distribution of somatostatin receptor binding and modulation of adenylyl cyclase activity in Alzheimer's disease brain. J. Neurosci. 105:225-233; 1991

5. Blaustein, J. D. The $\alpha_{1}$-noradrenergic antagonist prazosin decreases the concentration of estrogen receptors in female rat hypothalamus. Brain Res. 404:39-50; 1987.

6. Blaustein, J. D.; Letcher, B. Noradrenergic regulation of cytosol estrogen receptors in female rat hypothalamus: Possible role of $\alpha_{2-}$ noradrenergic receptors. Brain Res. 404:51-57; 1987.

7. Bokoch, G. M.; Katada, T.; Northup, J. K.; Hewlett, E. L.; Gilman, A. G. Identification of the predominant substrate for ADP-ribosylation by islet activating protein. I. Biol. Chem. 258:2072-2075; 1983.

8. Brazeau, P.; Vale, W.; Burgus, R.; Ling, N.; Rivier, J.; Guillemin, R. Hypothalamic polypeptide that inhibits the secretion of immunoreactive pituitary growth hormone. Science 129:77-79; 1972.

9. Brownstein, M.; Arimura, A.; Sato, H.; Schally, A. V.; Kizer, J. S. The regional distribution of somatostatin in the rat brain. Endocrinology 96:1456-1461; 1975 .

10. Bruno, J. F.; Xu, J.; Song, J.; Berelowitz, M. Tissue distribution of somatostatin receptor subtype messenger ribonucleic acid in the rat. Endocrinology 133:2561-2567; 1993.

11. Chauvel, P.; Trottier, S. Role of noradrenergic ascending system in extinction of epileptic phenomena. In: Delgado-Escueta, A. V.; Ward, A. A., Jr.; Woodbury, D. M.; Porter, R. J., eds. Basic mechanisms of the epilepsies - molecular and cellular approaches. New York: Raven Press: 1986;475-487.

12. Chesselet, M. F.; Reisine, T. Somatostatin regulates dopamine release in rat striatal slices and cat caudate nuclei. J. Neurosci. 3:232$236 ; 1983$.

13. Czernik, A. J.; Petrack, V. Somatostatin receptor binding in rat cerebral cortex. Characterization using a nonreducible somatostatin analog. J. Biol. Chem. 285:5525-5530; 1983.

14. Enjalbert, A.; Rasolonn-Janahary, R.; Moyse, E.; Kordon, C.; Epelbaum, J. Guanine nucleotide sensitivity of $\left[{ }^{125} I\right]$-iodo- $N$-Tyr-somatostatin binding in rat adenohypohysis and cerebral cortex. Endocrinology 113:822-824; 1983 .

15. Epelbaum, J. Somatostatin in the central nervous system: Physiology and pathologic modifications. Prog. Neurobiol. 27:63-100; 1986.

16. Epelbaum, J.; Tapia-Arancibia, L.; Kordon, C.; Enjalbert, A. Characterization, regional distribution and subcellular distribution of ${ }^{12.5} \mathrm{I}-$ Tyr'-somatostatin binding sites in rat brain. J. Neurochem. 38:1515$1523 ; 1982$.

17. Finley, J. C. W.; Maderdrut, J. L.; Roger, L. J.; Petrusz, P. The immunocytochemical localization of somatostatin-containing neu- rons in the rat central nervous system. Neuroscience 6:2173-2192; 1981

18. Garlind, A.; Fowler, C. J.; Alafuzoff, I.; Winblad, B.; Cowburn, R. F. Neurotransmitter-mediated inhibition of postmortem human brain adenylyl cyclase. J. Neural Transm. 87:113-124; 1992

19. Gilman, A. G. A protein binding assay for adenosine $3^{\prime}, 5^{\prime}$-cyclic monophosphate. Proc. Natl. Acad. Sci. USA 67:305-312;1970.

20. Glowinski, J.; Iversen, L. L. Regional studies of catecholamines in the rat brain. I. The disposition of $\left[{ }^{3} \mathrm{H}\right]$ norepinephrine, $\left[{ }^{3} \mathrm{H}\right]$ dopamine and $\left.{ }^{3} \mathrm{H}\right] \mathrm{DOPA}$ in various regions of the brain. J. Neurochem. 13:655-669; 1966.

21. Greenwood, F. C.; Hunter, W. M.; Glober, J. S. The preparation of ${ }^{131}$ I-labeled human growth hormone of high specific radioactivity. Biochem. J. 89:114-123; 1963.

22. Guijarro, L. G.; Couvineau, A.; Rodríguez-Pena, M. S.; et al. Vasoactive intestinal peptide receptors in rat liver after partial hepatectomy. Biochem. J. 285:515-520; 1992.

23. Havlicek, V.; Friesen, H. G. Comparison of behavioral effects of somatostatin and $\beta$-endorphin in animals. In: Collu, E., ed. Control nervous system effects of hypothalamic hormone and other peptides. New York: Raven Press; 1979:381-402.

24. Hökfelt, T.; Elde, T; Johansson, O.; et al. Distribution of peptidecontaining neurons. In: Lipton, M. A.; DiMascio, A.; Killam. K. F., eds. Psychopharmacology: A generation of progress. New York: Raven Press; 1986:39-66.

25. Houslay, M. D.; Metcalfe, J. C.; Warren, G. B.; Hesketh, T. R.; Smith, G. A. The glucagon receptor of rat liver plasma membrane can couple to adenylate cyclase without activating it. Biochim. Biophys. Acta 436:489-494; 1976.

26. Johansson, O.; Hökfelt, T.; Elde, R. P. Immunohistochemical distribution of somatostatin-like immunoreactivity in the central nervous system of the adult rat. Neuroscience 13:265-339; 1984.

27. Jones, L. S.; Gauger, L. L.; Davis, J. N. Anatomy of brain alpha adrenergic receptors: In vitro autoradiography with $\left[{ }^{125} \mathrm{I}\right] \mathrm{Heat}$. J. Comp. Neurol. 231:190-208; 1985.

28. Koch, B. D.; Schonbrunn, A. The somatostatin receptor is directly coupled to adenylate cyclase in $\mathrm{GH}_{4} \mathrm{C}_{1}$ pituitary cell membranes. Endocrinology 114:1784-1790; 1984.

29. Krantic, S.; Martel, J. C.; Weismann, D.; Pujol, J. F.; Quirion, R. Quantitative autoradiographic study of somatostatin receptors heterogeneity in the rat extrahypothalamic brain. Neuroscience 39:127$137 ; 1990$

30. Laburthe, M.; Breant, B.; Rouyer-Fessard, C. Molecular identification of receptors for vasoactive intestinal peptide in rat intestinal epithelium by covalent cross-linking. Evidence for two classes of binding sites with different structural and functional properties. Eur. J. Biochem. 139:181-187; 1984 .

31. Laemml, U. K. Cleavage of structural proteins during the assembly of the head of bacteriophage T4. Nature 227:680-685; 1970.

32. Levitt, P.; Moore, R. Y. Noradrenaline neuron innervation of the neocortex in the rat. Brain Res. 139:219-231; 1978.

33. Löscher, W.; Czuczwar, S. J. Comparison of drugs with different selectivity for central alpha $a_{1}$ and alpha $a_{2}$ adrenoceptors in animal models of epilepsy. Epilepsy Res. 1:165-172; 1987. 
34. Lowry, O. H.; Rosenbrough, N. J.; Farr, A. L.; Randall, R. J. Protein measurement with Folin phenol reagent. J. Biol. Chem. 193:265$275 ; 1951$.

35. Markstein, R.; Stöckli, K. A.; Reubi, J. C. Differential effects of somatostatin on adenylate cyclase as functional correlate for different brain somatostatin receptor subpopulations. Neurosci. Lett. 104:13-18; 1989.

36. Matozaki, T.; Sakamoto, C.; Nagao, M.; Baba, S. Phorbol ester or diacylglycerol modulates somatostatin binding to its receptors on rat pancreatic acinar cell membranes. J. Biol. Chem. 261:1414-1420; 1986.

37. McCarty, R.; Plunkett, L. M. Quantitative autoradiographic analysis of somatostatin binding sites in discrete areas of rat forebrain. Brain Res. Bull. 18:29-34; 1985

38. Michel, M. C.; Hanft, G.; Gross, G. $\alpha_{1 \mathrm{H}}$ but not $\alpha_{1 \mathrm{~A}}$ adrenoceptors mediate inositol phosphate generation. Naunyn Schmiedebergs Arch. Pharmacol. 341:385-387; 1990

39. Micheletti, G.; Warter, J. M.; Marescaux, C.; et al. Effects of drugs affecting noradrenergic neurotransmission in rats with spontaneous petit mal-like seizures. Eur. J. Pharmacol. 135:397-402; 1987.

40. Moyse, E.; Beaudet, A.; Bertherat, J.; Epelbaum, J. Light microscopic radioautographic localization of somatostatin binding sites in the brainstem of the rat. J. Chem. Neuroanat. 5:75-84; 1992.

41. Munson, P. J.; Rodbard, D. LIGAND: A versatile computerized approach for characterization of ligand binding systems. Anal. Biochem. 107:220-239; 1980.

42. Nagao, M.; Sakamoto, C.; Matozaki, T.; et al. Coupling of inhibitory GTP binding protein to sornatostatin receptors on rat cerebrocortical membranes. Folia Endocrinol. Jpn. 65:1357-1366; 1989.

43. Nishizuka, $Y$. The role of protein kinase $C$ in cell surface signal transduction and tumour promotion. Nature 308:693-698; 1984.

44. Nock, B.; Feder, H. H. $\alpha_{1}$-noradrenergic regulation of hypothalamic progestin receptors and guinea pig lordosis behaviour. Brain Res. 310:77-85; 1984.

45. Patel, J. C.; Reichlin, S. Somatostatin in hypothalamus, extrahypothalamic brain and peripheral tissues of the rat. Endocrinology 102:523-531; 1978 .

46. Petrusz, P.; Sar, M.; Grossinan, O. H.; Kizer, J. S. Synaptic terminals with somatostatin-like immunoreactivity in the rat brain. Brain Res. 137:181-187; 1977.

47. Pitkänen, A.; Sirviö, J.; Jclkkonen, J.; Reikkinen, P. Somatostatinlike immunoreactivity and somatostatin receptor binding in rat brain before and after pentylenetetrazol induced convulsion. Neuropeptides $7: 63-71 ; 1986$

48. Raynor, K.; Reisine, T. A.nalogs of somatostatin selectively label distinct subtypes of somatcstatin receptors in rat brain. J. Pharmacol. Exp. Ther. 251:510-517; 1989.
49. Reader, T. A.; Ferron, A.; Descarries, L.; Jasper, H. H. Modulatory role for biogenic amines in the cerebral cortex. Microiontophoretic studies. Brain Res. 160:217-229; 1979.

50. Reubi, J. C. Evidence for two somatostatin-14 receptor types in rat brain cortex. Neurosci. Lett. 49:259-263; 1984

51. Reubi, J. C. New specific radioligand for one subpopulation of brain somatostatin receptors. Life Sci. 36:1829-1836; 1985.

52. Reubi, J. C.; Perrin, M. H.; Rivier, J. E.; Vale, V. High affinity binding sites for a somatostatin-28 analogue in rat brain. Life Sci. 28:2191-2198; 1981 .

53. Scatchard, G. The attractions of proteins for small molecules and ions. Ann. NY Acad. Sci. 51:660-671; 1949.

54. Schettini, G.; Florio, T.; Meucci, O.; et al. Somatostatin inhibition of adenylate cyclase activity in different brain areas. Brain Res. 492:65-71; 1989

55. Seamon, K. B.; Daly, J. W. Forskolin: Its biological and chemical properties. In: Seamon, K. B.; Daly, J. W., eds. Advances in cyclic nucleotide and protein phosphorylation research. vol. 17. New York: Raven Press; 1986:1 - 150.

56. Smith, C. J.; Court, J. A.; Keith, A. B.; Perry, E. K. Increases in muscarinic-stimulated hydrolysis of inositol phospholipids in rat hippocampus following cholinergic differentiation are not paralleled by alterations in cholinergic receptor density. Brain Res. 485:317$324 ; 1989$.

57. Srikant, C. B.; Patel, Y. C. Somatostatin receptors: Identification and characterization in rat brain membranes. Proc. Natl. Acad. Sci. USA 78:3930-3934; 1981.

58. Tanaka, S.; Tsujimoto, S. Somatostatin facilitates the serotonin release from rat cerebral cortex, hippocampus and hypothalamus slices. Brain Res. 208:219-222; 1981.

59. Tran, V.; Beal, F.; Martin, J. Two types of somatostatin receptors differentiated by cyclic somatostatin analogs. Science 228:492-495; 1985.

60. Uhl, G. R.; Tran, V.; Snyder, S. H.; Martin, J. B. Somatostatin receptors: Distribution in rat central nervous system and human frontal cortex. J. Comp. Neurol. 240:288-304; 1985.

61. Viguerie, N.; Tahiri-Jouti, N.; Ayral, A.; et al. Direct inhibitory effects of a somatostatin analog, SMS 201-995, on AR4-2J cell proliferation via pertussis toxin-sensitive guanosine triphosphate-binding protein-independent mechanism. Endocrinology 124:1017$1025 ; 1989$.

62. Wang, H. L.; Bogen, C.; Reisine, T.; Dichter, M. Somatostatin-14 and somatostatin-28 induce opposite effects on potassium currents in rat neocortical neurons. Proc. Natl. Acad. Sci. USA 86:9616$9620 ; 1989$.

63. Wang, H. L.; Reisine, T.; Dichter, M. Somatostatin-14 and somatostatin-28 inhibit calcium current in rat neocortical neurons. Neuroscience 342:335-342; 1990. 